\title{
Renal profile and urinary fractional excretion of calcium, phosphorus, and magnesium of lambs fed with different contents of phosphorus
}

\section{Perfil renal e excreção fracionada urinária de cálcio, fósforo e magnésio de cordeiros alimentados com teores diferentes de fósforo}

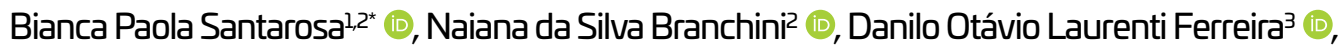 \\ Soraya Regina Sacco Surian ${ }^{4}$ (1), Daniela Marques Maciel Dabus² ${ }^{10}$, Henrique Barbosa Hooper ${ }^{5}$ (D),

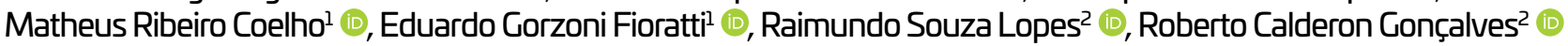

\begin{abstract}
Obstructive urolithiasis is common in confined sheep, and a predominant factor predisposing animals to this condition is nutritional management. The objective of this study was to evaluate the effect of different concentrations of phosphorus $(\mathrm{P})$ on urinalysis, serum urea and creatinine, and serum and urine concentrations of calcium (Ca), P, and magnesium $(\mathrm{Mg})$, as well as to establish the fractional excretion (FE) of these elements in confined lambs. Thirty male Santa Inês x Ile de France sheep at four months of age were divided into two groups according to the diet: Group $1(\mathrm{G} 1, \mathrm{n}=15)$, with $0.43 \% \mathrm{P}$ in their feed; and Group $2(\mathrm{G} 2, \mathrm{n}=15)$ with $0.65 \% \mathrm{P}$. The diets consisting of $10 \%$ Coast-cross hay and $90 \%$ of a concentrate of soybean meal, wheat, and crushed corn were provided for 90 consecutive days, with water ad libitum. The time points $(\mathrm{M})$ of blood and urine collection were determined as M0, immediately before the beginning of the diet, and at 15-day intervals: M1, M2, M3, M4, M5, and M6. Phosphorous-rich diets favored the appearance of triple phosphate crystals in both groups, causing calculogenesis in more than one third of the animals (11/30), emphasizing the relevance of conducting laboratory tests to aid in urolithiasis diagnosis. In addition, FE revealed an increased renal excretion of excess minerals in the diet, and therefore a greater predisposition for stone formation in relation to nutritional management.
\end{abstract}

KEYWORDS: Feedlot; Kidney; Sheep; Urinary obstruction; Urolithiasis

RESUMO: A urolitíase obstrutiva é frequente em ovinos confinados, sendo o manejo nutricional um dos fatores predisponentes mais importantes à formação dos cálculos. O objetivo desse estudo foi avaliar o efeito da alimentação, com diferentes concentrações de fósforo $(\mathrm{P})$, sobre a urinálise, ureia e creatinina séricas, concentração de cálcio $(\mathrm{Ca}), \mathrm{P}$ e magnésio $(\mathrm{Mg})$ séricos e urinários, bem como estabelecer a excreção fracionada (EF) desses elementos em cordeiros confinados. Utilizaram-se 30 ovinos machos, não castrados, Santa Inês x Ile de France, com quatro meses de idade, que foram divididos em dois grupos de acordo com a dieta: Grupo $1(\mathrm{G} 1, \mathrm{n}=15)$, com 0,43\% de P; e Grupo 2 (G2, n = 15) com 0,65\% de P. As dietas foram fornecidas por 90 dias consecutivos, com $10 \%$ de feno de Coast-cross; $90 \%$ de concentrado composto por farelo de soja, trigo e milho triturado; água ad libitum. Os momentos (M) de colheita de sangue e urina foram determinados como M0, imediatamente antes do início da dieta, e em intervalos de 15 dias nos momentos M1, M2, M3, M4, M5, M6. As dietas ricas em fósforo favoreceram o aparecimento de cristal fosfato triplo em ambos os grupos, o que provocou a calculogênese em um terço dos animais (11/30). Ressaltou-se a relevância da execução de exames laboratoriais para auxílio diagnóstico de urolitíase. Além disso, a EF comprovou a maior excreção renal dos minerais em excesso na dieta, que mostrou a maior predisposição para formação dos cálculos conforme o manejo nutricional.

PALAVRAS-CHAVE: confinamento; obstrução urinária; ovinos; rim; urolitíase.

\footnotetext{
Instituto de Ciências Agrárias (ICA) da Universidade Federal dos Vales do Jequitinhonha e Mucuri (UFVJM), Unaí/MG, Brasil ${ }^{2}$ Faculdade de Medicina Veterinária e Zootecnia (FMVZ), Universidade Estadual Paulista (UNESP), Botucatu/SP, Brasil. ${ }^{3}$ Secretaria da Agricultura e Abastecimento do estado de São Paulo, Defesa Agropecuária do estado de São Paulo, Bauru/SP, Brasil. ${ }^{4}$ Instituto Federal de Educação, Ciência e Tecnologia Catarinense, Concórdia/SC, Brasil.

${ }_{5}^{5}$ Faculdade de Zootecnia e Engenharia de Alimentos (FZEA), Universidade de São Paulo (USP), Pirassununga/SP, Brasil.

${ }^{*}$ Corresponding author: biancasantarosavet@gmail.com

Received: 10/02/2021. Accepted: 25/03/2021
} 


\section{INTRODUCTION}

Urolithiasis is a multifactorial pathological process characterized by the presence of stones in the urinary system, which has a high incidence in confined sheep (RIET-CORREA; SIMÓES; VASCONCELOS, 2008; GUIMARÁES et al., 2012). The disease particularly affects males, causing reproductive inability in rams and carcass conviction of lambs (ANTONELLI et al., 2012; FERREIRA et al., 2015).

Intensive breeding systems with a $\mathrm{Ca}$ : P imbalance or plants containing a large amount of silica or oxalate can trigger the disease (RIET-CORREA; SIMÓES; VASCONCELOS, 2008). Grain-dominated diets with high levels of phosphorus (P) and magnesium $(\mathrm{Mg})$, low concentrations of calcium $(\mathrm{Ca})$, and a $\mathrm{Ca}$ : $\mathrm{P}$ ratio ranging from 1:4 to $1: 6$ can influence the occurrence of urolithiasis (FREEMAN et al., 2010). The chemical imbalance results in increased excretion of $\mathrm{P}$ in the urine, which in ruminants is normally alkaline, therefore rendering the $\mathrm{P}$ insoluble, causing precipitation and consequent formation of crystals (FERREIRA et al., 2014; MACIEL et al., 2017).

Excretion of excess $\mathrm{P}$ in ruminants occurs through saliva from the rumination process. In intensive farming systems using diets containing a high concentration of grains and low roughage, saliva production is reduced, and a higher concentration of $\mathrm{P}$ is eliminated by the kidneys, contributing to the formation of uroliths (EMERICK; EMBRY, 1963; LOUVADINI; VITTI, 1994).

The optimal chemical composition of the feed must be determined to correct the factors that are involved in stone formation, and thus avoid the appearance of obstructive urolithiasis and the consequent economic losses (FERREIRA et al., 2015). In addition, mineral levels should be measured in the serum and urine in order to verify the homeostasis of these elements. Furthermore, it is necessary to ascertain the renal function of animals by determining the serum urea and creatinine, as they allow for the estimation of the glomerular filtration rate (SACCO; LOPES, 2011). Factors such as water intake and renal blood flow can interfere with this rate, thereby influencing the excretion of minerals. In addition, calculating the fractional excretion (FE) of the elements can verify their resorption and excretion, which also considers the urinary creatinine level (KING, 1994; FERREIRA et al., 2018). Thus, the aim of this work was to study the renal profile of lambs subjected to two diets with different levels of phosphorus, through urinalysis findings and serum urea and creatinine readings, as well as to determine the urinary FE of $\mathrm{Ca}, \mathrm{P}$, and $\mathrm{Mg}$.

\section{MATERIAL AND METHODS}

This work was submitted and approved by the Ethics Committee on the Use of Animals of the School of Veterinary Medicine and Animal Science (FMVZ), São Paulo State University (UNESP), Botucatu Campus, SP, Brazil, under protocol 156/2012. The average temperature was $21.03{ }^{\circ} \mathrm{C}$ and relative humidity was $71.38 \%$ in the period from September to December 2013.
Thirty male lambs, non-castrated, crossbred from the Ile de France and Santa Inês breeds from commercial flocks, recently weaned with an average age of 120 days and average live weight $(\mathrm{LW})$ of $18.7 \pm 1.2 \mathrm{~kg}$ were identified, separated, and randomly distributed into two groups of 15 animals (G1 and G2). Initially, the lambs were dewormed with $1 \%$ injectable Moxidectin $\left(200 \mu \mathrm{g} / \mathrm{kg}\right.$, Cidectin ${ }^{\circledR}$ Zoetis Indústria de Produtos Veterinarios Ltda, Campinas-SP, Brazil) and vaccinated against Clostridiosis (Sintoxan polyvalente $\mathrm{T}^{\circledR}$, Boehringer Ingelheim, Campinas-SP, Brazil). After a 15-day adaptation to the environment and diets, the animals were confined for 75 days for five collection samples, one every 15 days, totaling 90 days of confinement. The sheep were allocated to four collective $12 \mathrm{~m}^{2}$ masonry stalls, with seven or eight animals each (average of $1.5 \mathrm{~m}^{2} /$ head), all in the same location inside the Veterinary Hospital of FMVZ/UNESP, Botucatu. Two stalls were assigned to G1, with seven and eight animals, respectively, and the other two were allocated to G2, in which the animals were under the same nutritional conditions. The animals received water ad libitum in automatic drinkers.

There was a visual assessment of the leftovers, but it was not quantified in order to guarantee the daily adjustment of $10 \%$ of leftovers. The hay was crushed and mixed with the concentrate, which provided a complete homogeneous diet, and was offered in feeders with sufficient area available for all sheep to feed without dispute. The experiment covered the usual growth and finishing time of lambs for slaughter, weaning at 60 to 70 days of age at an average weight of $18 \mathrm{~kg}$, confining for 90 days, and reaching a final average weight of 40 $\mathrm{kg}$ at 150 to 160 days old (PIRES et al. 2000). During this period, the sheep presented an average daily consumption of $3 \%$ of the dry matter (DM) PV, following the recommendations of the NRC (2007). Thus, the animals had an average daily intake of DM of 1 to $1.3 \mathrm{~kg}$ and an average daily weight gain of $0.244 \mathrm{~g}$ (CIRNE et al., 2013).

The groups received diets differing in $\mathrm{Ca}$ and $\mathrm{P}$ ratios, but within the recommendations indicated by the NRC (2007) for raising sheep, using ratios of 1.9:1 for G1 and 1.5:1 for G2, as follows: G1-Ca 0.8\% (8 g/kg DM), P 0.43\% (4.3 g/ kg DM); and G2-Ca 0.97\% (9.7 g/kg DM), P 0.65\% (6.5 $\mathrm{g} / \mathrm{kg} \mathrm{DM}$ ). Based on the average consumption of $1 \mathrm{~kg} /$ day of DM, lambs from G1 ingested $8 \mathrm{~g}$ of $\mathrm{Ca}$ and $4.3 \mathrm{~g}$ of $\mathrm{P}$ per day, and animals in G2 consumed $9.7 \mathrm{~g}$ of $\mathrm{Ca}$ and $6.5 \mathrm{~g}$ of $\mathrm{P}$ per day. These values were above the absolute requirement for this animal category of $183 \mathrm{mg}$ of $\mathrm{Ca}$ and $103 \mathrm{mg}$ of $\mathrm{P}$ per $\mathrm{kg}$ of BW/day (GERASEEV et al., 2000; NRC, 2007). Based on this, at the end of the experiment lambs with $40 \mathrm{~kg} \mathrm{BW}$ would require $7.32 \mathrm{~g}$ of $\mathrm{Ca}$ and $4.12 \mathrm{~g}$ of $\mathrm{P}$ daily.

The chemical-bromatological composition and percentage of ingredients in the diets are listed in Table 1 . In order to ensure experimental safety, the diet of $10 \%$ crushed Coastcross hay and $90 \%$ concentrate (soy bran, wheat, and crushed corn), was subjected to chemical-bromatological analysis by the 
Department of Animal Improvement and Nutrition of FMVZ/ UNESP, Botucatu. The DM, Crude Protein (CP), Etheric Extract (EE), and Mineral Matter (MM) were analyzed by the Weende method, and the neutral detergent fiber (NDF) and acid detergent fiber (ADF) by the Van Soest procedure (VAN SOEST; WINE, 1967). Mineral analysis was performed at the Campineiro Institute for Soil and Fertilizer Analysis (ICASA) to determine the percentage of phosphorus, calcium, magnesium, potassium, sodium, and sulfur (BRANCHINI, 2014).

Urine and whole blood samples were collected for the following analyses: urinalysis, serum and urinary $\mathrm{Ca}, \mathrm{P}$ and $\mathrm{Mg}$ levels, serum urea, and serum and urinary creatinine, at seven points, M0 (immediately before the supply of the diets), and at 15-day intervals: M1 (15 days); M2 (30 days); M3 (45 days); M4 (60 days); M5 (75 days); and M6 (90 days).

Blood and urine samples were collected in the morning (06:00) before feeding, by haltering the sheep in a quadrupedal position. Urine was collected by natural, spontaneous urination or by induction after asphyxia for approximately 15 seconds (GARCIA-NAVARRO, 2005). After collecting at least $10 \mathrm{~mL}$ of urine in a sterile $70 \mathrm{~mL}$ flask (J. Prolab. Indústria e Comércio de Produtos para Laboratório Ltda., São José dos Pinhais-PR, Brazil), the samples were sent to the Commercial Pathology Laboratory Veterinary Clinic (Vida Vet ${ }^{\oplus}$, Botucatu-SP), for urinalysis. On physical examination, volume, appearance, and density were evaluated by

Table 1. Chemical-bromatological composition and percentage of ingredients in the diets of feedlot lambs subjected to diets with different levels of phosphorus, 0,43\% (Gl) and 0,65\% (G2).

\begin{tabular}{l|c|c}
\hline Variables & G1 & G2 \\
\hline DM (\%) & 86.82 & 87.59 \\
\hline CP (\%) & 19.22 & 18.39 \\
\hline EE (\%) & 2.33 & 2.91 \\
\hline MM (\%) & 4.97 & 5.02 \\
\hline NDF (\%) & 17.40 & 17.62 \\
\hline ADF (\%) & 6.43 & 6.50 \\
\hline Crude Energy (\%) & 3813 & 3876 \\
\hline Phosphorus (P-\%) & 0.43 & 0.65 \\
\hline Calcium (Ca - \%) & 0.8 & 0.97 \\
\hline Magnesium (\%) & 0.19 & 0.22 \\
\hline Potassium (\%) & 0.78 & 0.83 \\
\hline Sodium (\%) & 0.4 & 0.3 \\
\hline Sulfur (\%) & 0.14 & 0.14 \\
\hline Ca:P ratio & $1.9: 1$ & $1.5: 1$ \\
\hline crushed Coast-cross hay (\%) & 10 & 10 \\
\hline Soy bran (\%) & 26 & 21.40 \\
\hline Wheat bran (\%) & 8 & 15 \\
\hline Crushed corn (\%) & 54 & 51.3 \\
\hline Calcitic limestone (\%) & 2 & 2.3 \\
\hline
\end{tabular}

refractometry (Atago ${ }^{\circledast}$ T2 refractometer, NE Clinical, Atago Brasil Ltda. Ribeirão Preto-SP, Brazil); for the chemical examination dry biochemical reagent strips were used (Combur10 Test $^{\oplus}$, Roche Diagnóstica Brasil Ltda. São Paulo-SP, Brazil), to evaluate $\mathrm{pH}$, proteins $(\mathrm{mg} / \mathrm{dL})$, glucose $(\mathrm{mg} / \mathrm{dL})$, acetone, urobilinogen, bilirubin, occult blood, and bile salts.

For the sedimentoscopy exam, $5 \mathrm{~mL}$ of urine was centrifuged (Excelsa II, Fanen, São Paulo-SP, Brazil) in conical tubes at $400 \mathrm{~g}$ for $5 \mathrm{~min}$. Subsequently, after discarding the supernatant, $0.5 \mathrm{ml}$ of urine was used to identify possible cells for desquamation of the urinary tract (kidney, pelvis, bladder, and urethral cells), along with prostate cells and other structures such as red blood cells, leukocytes, cylinders, bacteria, sperm, mucus, and crystals. Large-field magnification counting (cga) was performed with ordinary optical microscopy, using $400 x$ magnification. Urine aliquots were then stored in $2 \mathrm{~mL}$ tubes in a $-20^{\circ} \mathrm{C}$ freezer (Eppendorf do Brasil Ltda. São Paulo-SP, Brazil), for subsequent mineral dosing.

Samples of $10 \mathrm{~mL}$ of blood from the jugular vein of each animal were collected in vacuum tubes without anticoagulant (BD Vacutainer ${ }^{\oplus}$, BD Medical, Curitiba-PR, Brazil) at each sampling point (M0, M1, M2, M3, M4, M5 M6, and M7). After the clot retraction, the samples were centrifuged (Combate Celm ${ }^{\circledast}$ - Cia. Equipadora de Laboratórios Modernos, Barueri-SP, Brazil) at $2000 \mathrm{~g}$ for $5 \mathrm{~min}$ to obtain serum, and subsequently frozen at $-20^{\circ} \mathrm{C}$ in $2 \mathrm{~mL}$ aliquots in tubes.

Biochemical analyses were performed at the Service of Clinical Pathology, Department of Veterinary Clinic, FMVZ / UNESP, Botucatu, using commercial reagents (Kata ${ }^{\circledast}$ Biotecnológica Ind. Com. Ltda. Belo Horizonte-MG, Brazil) by reading on a spectrophotometer (SB- $190 \mathrm{Celm}^{\oplus}$ - Company of Modern Laboratories, Barueri-SP, Brazil). Serum measurements were performed according to the following methods: colorimetric enzyme to determine the urea concentration (modified Berthelot); colorimetric kinetic for creatinine (Jaffe); and colorimetric for Ca (cresolphthalein complexone), P (ammonium molybdate), and $\mathrm{Mg}$ (sulfonated Magon). The dosage of calcium and phosphorus were obtained after acidification of the samples, in accordance with the technique described by Fleming et al. (1991).

Serum and urine electrolytes and creatinine were measured, and the fractional excretion calculations were performed. Thus, it was possible to compare the electrolyte clearance with that of endogenous creatinine to determine the renal excretion of this element, using the concentrations of urinary electrolytes $(\mathrm{EU})$, urinary creatinine (CRU), serum electrolytes (ES), and serum creatinine (CRS). Fractional excretion was calculated: FE $(\%)=[(E U / E S)$ $\mathrm{x}(\mathrm{CRS} / \mathrm{CRU})] \times 100$ according to LEFEBVRE et al. (2008).

The distribution of the studied variables was considered for the choice of statistical methods, descriptive statistics, and non-parametric analyses. Due to the non-normal distribution of the results, the medians for the Wilcoxon nonparametric test were used to assess the difference between the groups (G1 and G2), within each of the seven sampling 
points (M0 to M6). The correlation between the variables was estimated by Spearman's correlation coefficient. The analyses were performed with the SAS software (SAS Institute, 2011), adopting a significance level of $5 \%(\mathrm{p}<0.05)$.

\section{RESULTS AND DISCUSSION}

During the experiment, three lambs presented obstructive urolithiasis, two lambs from G1 (2/15) and one lamb from G2 (1/15). At the end of the experiment, eight more animals showed phosphate calculations in the urinary system at necroscopy, four from each group for a total of $36.67 \%$ (11/30) of lambs that developed the condition.

\section{Urinalysis}

The urinary density averages (Table 2) of the samples remained between 1010 and 1020, which is within the standard of normality of 1015-1045 (GARCIA-NAVARRO, 2005; ARAÚJO et al., 2009). Comparing the experimental groups, only M2 and M5 showed a difference in urinary density $(\mathrm{p}<0.05)$, with G1

Table 2. Urinary density and $\mathrm{pH}$ of feedlot lambs subjected to diets with different levels of phosphorus, 0,43\% (Gl) and $0,65 \%(\mathrm{CZ})$, at different sampling times (M).

\begin{tabular}{|c|c|c|c|c|c|}
\hline \multirow{2}{*}{ Times } & \multirow{2}{*}{ Variables } & \multicolumn{2}{|c|}{$G 1(n=15)$} & \multicolumn{2}{|c|}{$G 2(n=15)$} \\
\hline & & $\bar{X} \pm s$ & md & $\bar{X} \pm s$ & Md \\
\hline \multirow[t]{2}{*}{ MO } & Density & $\begin{array}{c}1011.8 \pm \\
8.2\end{array}$ & 1010.0 & $\begin{array}{c}1016.9 \pm \\
7.7\end{array}$ & 1017.5 \\
\hline & $\mathrm{pH}$ & $8.3 \pm 1.0$ & 9.0 & $7.9 \pm 1.1$ & 8.0 \\
\hline \multirow[t]{2}{*}{$\mathrm{Ml}$} & Density & $\begin{array}{c}1013.0 \\
\pm 7.7\end{array}$ & 1010.0 & $\begin{array}{c}1017.7 \pm \\
7.5\end{array}$ & 1020.0 \\
\hline & $\mathrm{pH}$ & $8.1 \pm 1.0$ & $8.0^{A}$ & $7.4 \pm 0.9$ & $7.5^{\mathrm{B}}$ \\
\hline \multirow[t]{2}{*}{$M 2$} & Density & $\begin{array}{c}1017.0 \pm \\
5.6\end{array}$ & $1020.0^{A}$ & $\begin{array}{c}1018.3 \pm \\
8.8\end{array}$ & $1015.0^{B}$ \\
\hline & $\mathrm{pH}$ & $7.6 \pm 0.9$ & 8.0 & $7.2 \pm 1.2$ & 7.0 \\
\hline \multirow[t]{2}{*}{ M3 } & Density & $\begin{array}{c}1017.9 \pm \\
5.8\end{array}$ & 1015.0 & $\begin{array}{c}1020.0 \\
\pm 6.8\end{array}$ & 1020.0 \\
\hline & $\mathrm{pH}$ & $7.4 \pm 0.9$ & 7.0 & $7.0 \pm 0.9$ & 7.0 \\
\hline \multirow[t]{2}{*}{ M4 } & Density & $\begin{array}{c}1021.8 \\
\pm 9.1\end{array}$ & 1020.0 & $\begin{array}{c}1013.2 \pm \\
8.0\end{array}$ & 1012.5 \\
\hline & $\mathrm{pH}$ & $7.5 \pm 1.3$ & 8.0 & $7.8 \pm 1.1$ & 8.0 \\
\hline \multirow[t]{2}{*}{ M5 } & Density & $\begin{array}{c}1020.4 \pm \\
5.2\end{array}$ & $1020.0^{A}$ & $\begin{array}{c}1014.3 \pm \\
8.1\end{array}$ & $1015.0^{\mathrm{B}}$ \\
\hline & $\mathrm{pH}$ & $6.8 \pm 1.2$ & 6.5 & $7.4 \pm 1.0$ & 8.0 \\
\hline \multirow[t]{2}{*}{ M6 } & Density & $\begin{array}{c}1014.6 \pm \\
9.7\end{array}$ & 1015.0 & $\begin{array}{c}1013.9 \pm \\
9.4\end{array}$ & 1010.0 \\
\hline & $\mathrm{pH}$ & $7.6 \pm 1.2$ & 7.0 & $7.4 \pm 1.0$ & 8.0 \\
\hline
\end{tabular}

Mean $(\bar{X})$, standard desviation (s) e median (md).

$\mathrm{A}, \mathrm{B}$ Medians followed by different capital letters on the line differ statistically between groups within the time point by the Wilcoxon Test $(p<0.05)$.

Urinary density: 1015-1045; pH: 6.0-8.5 (GARCIA-NAVARRO, 2005). showing higher medians than G2, indicating that the urine was more concentrated at these times. Similar to this study, Ferreira et al. (2020) reported that the urine density of confined lambs remained within normal values. Urinary density varies according to the degree of hydration, as well as the presence of other sediments such as flaking cells, crystals, and cylinders (ARAÚJO et al., 2009). Although some samples points revealed greater density in G1, the factors related to the high concentration of solutes, which caused urine supersaturation with calculogenic crystalloids (ARAÚJO et al., 2009), occurred in both groups, favoring the formation of uroliths in 11 lambs.

The average $\mathrm{pH}$ values ranged from 6.5 to 8.0 , within the normal range for sheep of 6.0-8.5, according to GarciaNavarro (2005). There was a difference between groups in M1 only ( 15 days of confinement), when G1 had a higher median than G2, but subsequently there was no significant variation between groups, although the median of G2 was higher in M5 and M6. Physiologically, the urine $\mathrm{pH}$ of ruminants is alkaline, which favors the precipitation of solutes (GARCIANAVARRO, 2005; ARAÚJO et al., 2009).

In a contrasting study with sheep, Ferreira et al. (2014) observed that even before treatment with ammonium chloride and vitamin $\mathrm{C}$, a lower $\mathrm{pH}$ in relation to the normal $\mathrm{pH}$ of the species was observed in the three groups studied when they did not receive urinary acidifier, which can be explained by the richness of the concentrate diet. Ferreira et al. (2020) observed the effectiveness of urinary acidification in sheep treated with $400 \mathrm{mg} / \mathrm{kg} / \mathrm{PV}$ of ammonium chloride/day and the failure of $4 \mathrm{mg} / \mathrm{kg}$ of vitamin $\mathrm{C}$, both administered orally.

Although they were receiving different treatments, the two experimental groups in the present study showed similar results in urinalysis. The variables (results): color (light to dark yellow), appearance (clear or slightly cloudy), protein (absent or + ), glucose (absent), urobilinogen (normal), bilirubin (absent), occult blood (absent), red blood cells (absent or rare), urinary tract cells (renal, pelvic, bladder, and urethral absent or rare), cylinders (absent) and mucus (absent) were not statistically different between the groups and remained within the normal range for the species (GARCIA-NAVARRO, 2005; ARAÚJO et al., 2009).

The median urinary leukocyte count showed a statistical difference $(\mathrm{p}<0.05)$ between groups only at M0, with G2 showing higher values compared to G1 (Table 3). G1 presented normal values of up to five/cga (GARCIA-NAVARRO, 2005) in six of the seven collection points studied, however, in M5 there was an inversion with G2, revealing counts above five/ cga in M0, M1, M2, M3, M4 and M6. There is a need for an organic matrix for deposition of inorganic crystals for calculogenesis, which develop into the urolith, a mucopolysaccharide or mucoprotein where leukocytes, fibrin, cellular debris, and/ or bacteria are deposited (ARAÚJO et al., 2009). Therefore, this leukocyturia may have contributed to the matrix for the calculations formed, particularly in G2. 
The bacteria count in the urine (Table 3) was within the normal parameters between the groups and the sample times of up to five/cga (GARCIA-NAVARRO, 2005). G2 showed higher values when compared to G1, with a statistical difference $(\mathrm{p}<0.05)$ at M2 and M4. Urinary tract infection is an important factor in the development of urolithiasis, since bacterial colonization favors the appearance of organic nuclei and modifies the secretion of inhibitory elements by the inflammatory process. More importantly, urease-producing bacteria change the $\mathrm{pH}$ level of urine (SACCO; LOPES, 2011). Thus, bacteriuria and leukocyturia in G2 associated with a more alkaline $\mathrm{pH}$, especially at the end of the experiment, favored the appearance of uroliths in these animals.

The presence of triple phosphate crystals (Figure 1) was constant from the first urine collection to the end of the experiment. There was no significant difference between the groups, although it was observed that G1 always returned higher values than G2, with the exception of M4 and M6 (Figure 2). Triple phosphate crystals can be formed in alkaline, neutral, or slightly acidic $\mathrm{pH}$, but they are more prominent in a basic pH (SUN et al., 2010; JONES et al., 2017). In the present study, triple phosphate crystals occurred because of the high levels of phosphorus in the diet, and they were more evident in G1 where an alkaline $\mathrm{pH}$ was observed in five sample points, M0, M1, M2, M4, and M6.

Table 3. Leukocyte and bacteria count in urine of feedlot lambs subjected to diets with different levels of phosphorus, 0,43\% (Gl) and 0,65\%(G2), at different sampling times (M).

\begin{tabular}{c|c|c|c|c|c}
\multirow{2}{*}{ Times } & \multirow{2}{*}{ Variables } & \multicolumn{2}{|c|}{$\mathbf{G 1}(\mathbf{n = 1 5})$} & \multicolumn{2}{c}{ G2 (n=15) } \\
\cline { 3 - 6 } & & $\bar{X} \pm s$ & $\mathbf{m d}$ & $\bar{X} \pm s$ & $\mathbf{m d}$ \\
\hline \multirow{3}{*}{ M0 } & Leukocyte & $7.4 \pm 8.7$ & $3.3^{\mathrm{A}}$ & $12.4 \pm 10.3$ & $9.0^{\mathrm{B}}$ \\
\cline { 2 - 6 } & Bacteria & $0.6 \pm 0.8$ & 0.0 & $1.1 \pm 1.1$ & 1.0 \\
\hline \multirow{2}{*}{ M1 } & Leukocyte & $6.4 \pm 5.2$ & 3.5 & $9.0 \pm 5.4$ & 9.0 \\
\cline { 2 - 6 } & Bacteria & $0.7 \pm 1.0$ & 0.0 & $1.1 \pm 0.9$ & 1.0 \\
\hline \multirow{2}{*}{ M2 } & Leukocyte & $4.9 \pm 3.0$ & 4.0 & $14.3 \pm 12.7$ & 8.0 \\
\cline { 2 - 6 } & Bacteria & $0.3 \pm 0.6$ & $0.0^{\mathrm{A}}$ & $1.3 \pm 1.2$ & $1.0^{\mathrm{B}}$ \\
\hline \multirow{2}{*}{ M3 } & Leukocyte & $26.9 \pm 41.4$ & 3.3 & $46.6 \pm 52.5$ & 6.0 \\
\cline { 2 - 6 } & Bacteria & $0.9 \pm 1.1$ & 0.5 & $1.3 \pm 0.9$ & 1.0 \\
\hline \multirow{2}{*}{ M4 } & Leukocyte & $14.4 \pm 28.1$ & 5.0 & $23.6 \pm 35.5$ & 7.0 \\
\cline { 2 - 6 } & Bacteria & $0.5 \pm 0.7$ & $0.0^{\mathrm{A}}$ & $1.9 \pm 1.4$ & $2.0^{\mathrm{B}}$ \\
\hline \multirow{2}{*}{ M5 } & Leukocyte & $11.7 \pm 10.0$ & 11.0 & $9.5 \pm 9.4$ & 5.0 \\
\cline { 2 - 6 } & Bacteria & $1.1 \pm 1.5$ & 0.0 & $1.1 \pm 1.4$ & 1.0 \\
\hline \multirow{2}{*}{ M6 } & Leukocyte & $12.5 \pm 24.2$ & 2.5 & $24.3 \pm 38.5$ & 7.5 \\
\hline & Bacteria & $0.6 \pm 1.0$ & 0.0 & $0.4 \pm 0.8$ & 0.0 \\
\hline
\end{tabular}

Mean $(\bar{X})$, standard desviation (s) e median (md).

A,B Medians followed by different capital letters on the line differ statistically between groups within the time point by the Wilcoxon Test $(p<0.05)$

Leukocytes: up to five/cga; Bacterias: up to five/cga (GARCIANAVARRO, 2005).
The difference between animals in terms of the presence of crystals was evaluated (Table 4) with two subgroups (Gc calculation and $\mathrm{Gw}$ - without calculation). In this analysis, it was possible to observe that the animals that produced urinary stones presented a greater quantity of crystals in the urine, with statistical differences in M2, M3, M4, and M6. This was first noted at 30 days of confinement (M2) due to the elapsed time of depositing solutes in the lambs' urine, which was sufficient to show crystalluria, due to the excessive intake of minerals present in the diet. There was a decrease in the crystal count in the last collection points (M5 and M6), likely a result of the cementation of the calculations, since the formation occurs from the precipitation of solutes in the form of crystals around the organic matrix nucleus (FERREIRA et al., 2015).

\section{Serum dosage of urea and creatinine}

During the experiment, the urea concentration (Table 5) of the confined lambs subjected to diets with different levels of $\mathrm{P}$ ranged from $42.70 \mathrm{mg} / \mathrm{dL}$ to $90.40 \mathrm{mg} / \mathrm{dL}$, which were above the reference level of $17.12-42.80 \mathrm{mg} / \mathrm{dL}$ (KANEKO et al., 2008). There was a difference between the groups at M5 and

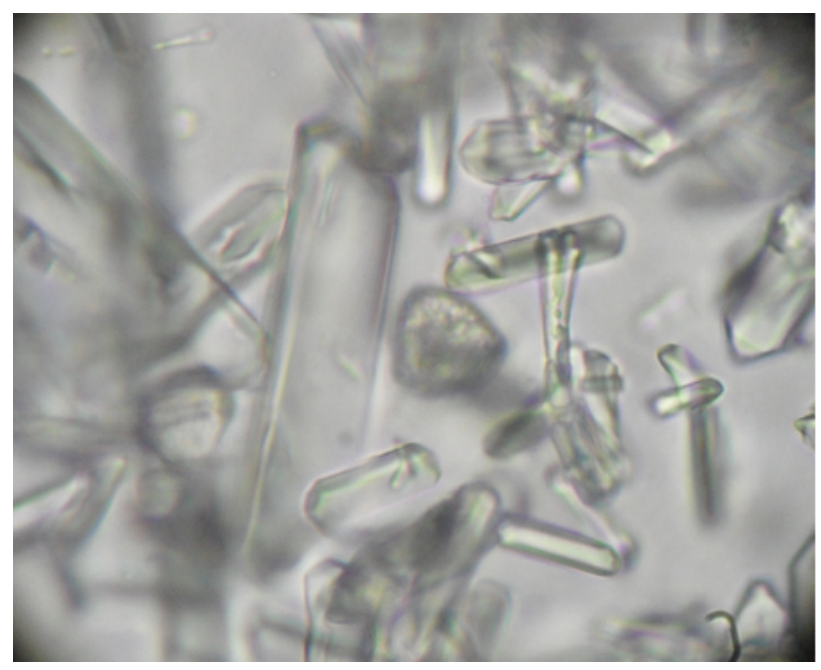

Figure 1. Triple phosphate crystals observed under the microscope, at $400 \times$ magnification.

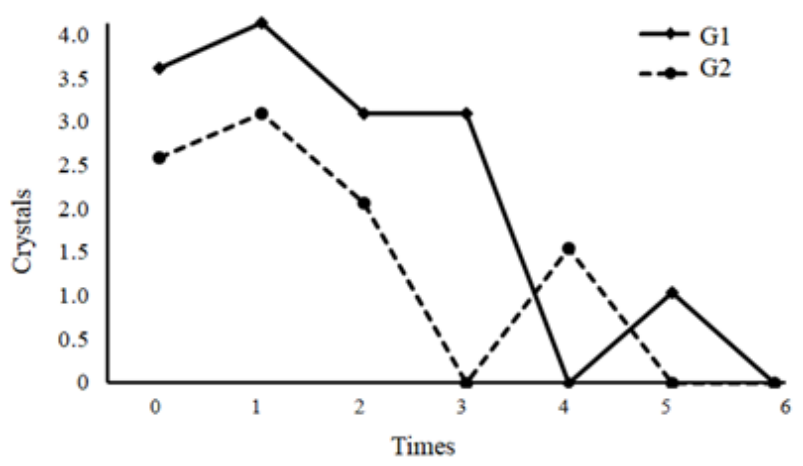

Figure 2. Variation in the presence of crystals (crosses by large field of increase) between the groups with a diet composed of $0.43 \%$ (Gl) and $0.65 \%$ (G2) of $P$, at different times. 
M6 ( $\mathrm{p}<0.05$ ), with G1 revealing higher medians than G2, since two animals obstructed in G1 causing post-renal azotemia. The values obtained for urea were similar to those obtained by VinodhKumar et al. (2010), who reported serum urea values above the reference range, even in healthy animals. These authors identified levels of $45.28 \mathrm{mg} / \mathrm{dL}$ in lambs considered healthy, $67.38 \mathrm{mg} / \mathrm{dL}$ in suspect animals, and $146.34 \mathrm{mg} / \mathrm{dL}$ in those with confirmed urolithiasis. In the present study, the mean serum urea and creatinine levels of sheep with urolithiasis were $143.73 \mathrm{mg} / \mathrm{dL}$ and $1.98 \mathrm{mg} / \mathrm{dL}$, respectively.

According to Rennó et al. (2000), the serum dosage of urea is influenced by the high concentration of CP in the diet, which in the present study was $19.22 \%$ and $18.39 \%$ in the respective groups G1 and G2 (Table 1), therefore the high urea levels may be a consequence of the concentrate-rich diet.

Serum creatinine values (Table 5) ranged from 0.68 to $1.71 \mathrm{mg} / \mathrm{dL}$ during the experiment, within the reference level of 1.2 to $1.9 \mathrm{mg} / \mathrm{dL}$ (KANEKO et al., 2008). The two groups returned similar results, apart from in M4, where G2 showed a higher median than G1. Creatinine proved to be a more efficient marker of kidney damage than urea because it was not influenced by the diet, and therefore faithfully represented the glomerular filtration rate. The serum creatinine showed no values above the reference, which indicated that the diets did not compromise the functioning of the nephrons (KOZLOSKI et al., 2005; KIRSZTAJN, 2007).

\section{Serum, urine, and FE measurement of $\mathrm{Ca}, \mathrm{P}$, and $\mathrm{Mg}$}

The serum Ca values (Table 6) were below the reference values (MACIEL et al., 2016; FERREIRA et al., 2020) for the sheep species, which are 4.82 to $9.37 \mathrm{mg} / \mathrm{dL}$. There was a statistical difference between the groups only at two times, M1 (15 days of the diet) and M2 (30 days), when G2 showed higher medians than G1 since the Ca concentration in the G2 diet

Table 4. Count of crystals (represented by crosses) in the urine of feedlot lambs subjected to diets with different levels of phosphorus, with urinary calculations (Gc) and without (Gw), at different sampling times (M).

\begin{tabular}{l|c|c|c|c}
\multirow{2}{*}{ Times } & \multicolumn{2}{|c}{$G c(n=11)$} & \multicolumn{2}{c}{$G w(n=19)$} \\
\cline { 2 - 5 } & $\bar{X} \pm s$ & md & $\bar{X} \pm s$ & md \\
\hline M0 & $3.27 \pm 1.42$ & 4.00 & $2.25 \pm 1.65$ & 2.50 \\
\hline M1 & $3.45 \pm 1.29$ & 4.00 & $2.42 \pm 1.84$ & 3.00 \\
\hline M2 & $3.36 \pm 0.67$ & $3.00^{A}$ & $1.79 \pm 1.72$ & $2.00^{\mathrm{B}}$ \\
\hline M3 & $3.30 \pm 1.25$ & $4.00^{A}$ & $0.89 \pm 1.32$ & $0.00^{\mathrm{B}}$ \\
\hline M4 & $2.11 \pm 1.17$ & $3.00^{\mathrm{A}}$ & $1.06 \pm 1.47$ & $0.00^{\mathrm{B}}$ \\
\hline M5 & $1.89 \pm 1.83$ & 1.00 & $0.72 \pm 1.13$ & 0.00 \\
\hline M6 & $1.89 \pm 1.76$ & $2.00^{\mathrm{A}}$ & $0.39 \pm 0.98$ & $0.00^{\mathrm{B}}$ \\
\hline
\end{tabular}

Mean $(\bar{X})$, standard desviation (s) e median (md).

$\mathrm{A}, \mathrm{B}$ Medians followed by different capital letters on the line differ statistically between groups within the time point by the Wilcoxon Test $(p<0.05)$.
$(0.97 \%)$ was greater than G1 $(0.8 \%)$. According to Ferreira et al. $(2018 ; 2020)$, urolithiasis is more frequent in confined animals, where the feed generally consists of grains, since this type of food normally has a high content of $\mathrm{P}$ and $\mathrm{Mg}$, but a low level of $\mathrm{Ca}$. However, in this study, the Ca concentration was higher, and an increase in serum Ca values of M0 was observed in relation to M6 for both groups.

The urinary Ca dosage (Table 6) presented levels between 0.69 $\mathrm{mg} / \mathrm{dL}$ and $3.39 \mathrm{mg} / \mathrm{dL}$, differing in G2 having greater medians than G1 in M0 and M1 only. Ferreira et al. (2020) reported a broad value for urinary calcium in their control group but with a higher average. Tiruneh (2006) studied biochemical changes in the urine of cattle from farms with a history of urolithiasis, and observed that animals affected by urolithiasis had low urinary Ca.

Table 5. Serum urea $(\mathrm{mg} / \mathrm{dL})$ and creatinine $(\mathrm{mg} / \mathrm{dL})$ dosages of feedlot lambs subjected to diets with different levels of phosphorus, $0,43 \%(\mathrm{Gl})$ and $0,65 \%(\mathrm{G} 2)$, at different sampling times (M).

\begin{tabular}{|c|c|c|c|c|c|}
\hline \multirow{2}{*}{ Times } & \multirow{2}{*}{ Variables } & \multicolumn{2}{|c|}{ G $1(n=15)$} & \multicolumn{2}{|c|}{ G2 $(n=15)$} \\
\hline & & $\bar{X} \pm s$ & md & $\bar{X} \pm s$ & md \\
\hline \multirow{2}{*}{ MO } & Urea & $\begin{array}{c}47,56 \pm \\
12,49\end{array}$ & 42,70 & $\begin{array}{c}51,28 \pm \\
20,81\end{array}$ & 45,30 \\
\hline & Creatinine & $\begin{array}{c}0,75 \pm \\
0,13\end{array}$ & 0,73 & $\begin{array}{c}0,69 \pm \\
0,18\end{array}$ & 0,69 \\
\hline \multirow{2}{*}{$\mathrm{Ml}$} & Urea & $\begin{array}{c}46,56 \pm \\
11,52\end{array}$ & 48,90 & $\begin{array}{c}55,33 \pm \\
35,54\end{array}$ & 47,10 \\
\hline & Creatinine & $\begin{array}{c}0,78 \pm \\
0,29\end{array}$ & 0,68 & $\begin{array}{c}0,89 \pm \\
0,32\end{array}$ & 0,84 \\
\hline \multirow{2}{*}{$M 2$} & Urea & $\begin{array}{c}63,40 \pm \\
23,93\end{array}$ & 62,10 & $\begin{array}{c}69,37 \pm \\
14,63\end{array}$ & 70,00 \\
\hline & Creatinine & $\begin{array}{c}0,79 \pm \\
0,17\end{array}$ & 0,81 & $\begin{array}{c}0,82 \pm \\
0,16\end{array}$ & 0,79 \\
\hline \multirow{2}{*}{ M3 } & Urea & $\begin{array}{c}86,66 \pm \\
44,04\end{array}$ & 74,40 & $\begin{array}{c}75,06 \pm \\
17,17\end{array}$ & 74,00 \\
\hline & Creatinine & $\begin{array}{c}0,91 \pm \\
0,23\end{array}$ & 0,91 & $\begin{array}{c}0,95 \pm \\
0,24\end{array}$ & 0,94 \\
\hline \multirow{2}{*}{ M4 } & Urea & $\begin{array}{c}68,42 \pm \\
24,90\end{array}$ & 69,60 & $\begin{array}{c}73,52 \pm \\
15,96\end{array}$ & 75,20 \\
\hline & Creatinine & $\begin{array}{c}1,28 \pm \\
0,37\end{array}$ & $1,25^{\mathrm{B}}$ & $\begin{array}{c}1,54 \pm \\
0,31\end{array}$ & $1,53^{A}$ \\
\hline \multirow{2}{*}{ M5 } & Urea & $\begin{array}{c}82,75 \pm \\
22,47\end{array}$ & $82,20^{A}$ & $\begin{array}{c}61,99 \pm \\
10,91\end{array}$ & $64,65^{\mathrm{B}}$ \\
\hline & Creatinine & $\begin{array}{c}1,51 \pm \\
0,46\end{array}$ & 1,37 & $\begin{array}{c}1,34 \pm \\
0,30\end{array}$ & 1,32 \\
\hline \multirow{2}{*}{ M6 } & Urea & $\begin{array}{c}96,61 \pm \\
32,63\end{array}$ & $90,40^{A}$ & $\begin{array}{c}64,10 \pm \\
14,97\end{array}$ & $65,75^{\mathrm{B}}$ \\
\hline & Creatinine & $\begin{array}{c}1,63 \pm \\
0,59\end{array}$ & 1,53 & $\begin{array}{c}1,72 \pm \\
0,31\end{array}$ & 1,71 \\
\hline
\end{tabular}

Mean ( $\bar{X}$ ), standard desviation (s) e median (md).

A,BMedians followed by different capital letters on the line differ statistically between groups within the time point by the Wilcoxon Test $(p<0.05)$.

Urea: $17,12-42,8 \mathrm{mg} / \mathrm{dL}$; Creatinine: $1,2-1,9 \mathrm{mg} / \mathrm{dL}$ (KANEKO et al., 2008). 
Table 6. Serum (mg/dL), urinary (mg/dL), and FE (\%) of Ca of feedlot lambs subjected to diets with different levels of phosphorus, 0,43\% (Gl) and 0,65\%(G2), at different sampling times $(M)$.

\begin{tabular}{|c|c|c|c|c|c|}
\hline \multirow{2}{*}{ Timess } & \multirow{2}{*}{ Variables } & \multicolumn{2}{|c|}{ G $1(n=15)$} & \multicolumn{2}{|c|}{$\mathrm{G} 2(n=15)$} \\
\hline & & $\bar{X} \pm s$ & md & $\bar{X} \pm s$ & md \\
\hline \multirow{3}{*}{ MO } & Serum & $\begin{array}{c}6.22 \pm \\
1.95\end{array}$ & 5.89 & $\begin{array}{c}7.26 \pm \\
2.96\end{array}$ & 7.41 \\
\hline & Urinary & $\begin{array}{c}1.43 \pm \\
1.44\end{array}$ & $0.94^{B}$ & $\begin{array}{c}4.40 \pm \\
3.42\end{array}$ & $2.63^{A}$ \\
\hline & FE & $\begin{array}{c}0.20 \pm \\
0.17\end{array}$ & $0.18^{B}$ & $\begin{array}{c}1.09 \pm \\
1.88\end{array}$ & $0.52^{A}$ \\
\hline \multirow{3}{*}{$\mathrm{Ml}$} & Serum & $\begin{array}{c}6.44 \pm \\
2.79\end{array}$ & $5.57^{B}$ & $\begin{array}{c}7.82 \pm \\
1.74\end{array}$ & $7.76^{A}$ \\
\hline & Urinary & $\begin{array}{c}1.09 \pm \\
0.83\end{array}$ & $0.69^{B}$ & $\begin{array}{c}3.15 \pm \\
2.19\end{array}$ & $2.43^{A}$ \\
\hline & $\mathrm{FE}$ & $\begin{array}{c}0.25 \pm \\
0.34\end{array}$ & $0.13^{\mathrm{B}}$ & $\begin{array}{c}0.66 \pm \\
0.63\end{array}$ & $0.46^{A}$ \\
\hline \multirow{3}{*}{$M 2$} & Serum & $\begin{array}{c}5.91 \pm \\
1.84\end{array}$ & $5.42^{B}$ & $\begin{array}{c}7.93 \pm \\
0.88\end{array}$ & $8.06^{A}$ \\
\hline & Urinary & $\begin{array}{c}1.42 \pm \\
1.12\end{array}$ & 1.08 & $\begin{array}{c}1.96 \pm \\
2.05\end{array}$ & 1.37 \\
\hline & $\mathrm{FE}$ & $\begin{array}{c}0.20 \pm \\
0.15\end{array}$ & 0.14 & $\begin{array}{c}0.23 \pm \\
0.19\end{array}$ & 0.14 \\
\hline \multirow{3}{*}{ M3 } & Serum & $\begin{array}{c}5.20 \pm \\
1.94\end{array}$ & 4.82 & $\begin{array}{c}6.16 \pm \\
3.09\end{array}$ & 6.08 \\
\hline & Urinary & $\begin{array}{c}2.44 \pm \\
1.60\end{array}$ & 1.72 & $\begin{array}{c}4.32 \pm \\
4.32\end{array}$ & 2.44 \\
\hline & $\mathrm{FE}$ & $\begin{array}{c}0.25 \pm \\
0.08\end{array}$ & $0.24^{B}$ & $\begin{array}{c}0.51 \pm \\
0.41\end{array}$ & $0.35^{A}$ \\
\hline \multirow{3}{*}{ M4 } & Serum & $\begin{array}{c}8.60 \pm \\
3.37\end{array}$ & 7.78 & $\begin{array}{c}8.76 \pm \\
3.17\end{array}$ & 9.37 \\
\hline & Urinary & $\begin{array}{c}2.86 \pm \\
1.78\end{array}$ & 2.44 & $\begin{array}{c}2.42 \pm \\
1.74\end{array}$ & 2.23 \\
\hline & $\mathrm{FE}$ & $\begin{array}{c}0.68 \pm \\
0.54\end{array}$ & 0.50 & $\begin{array}{c}1.21 \pm \\
0.73\end{array}$ & 1.12 \\
\hline \multirow{3}{*}{ M5 } & Serum & $\begin{array}{c}7.91 \pm \\
3.12\end{array}$ & 7.07 & $\begin{array}{c}8.89 \pm \\
3.02\end{array}$ & 8.09 \\
\hline & Urinary & $\begin{array}{c}2.75 \pm \\
1.06\end{array}$ & 2.56 & $\begin{array}{c}2.36 \pm \\
1.00\end{array}$ & 2.31 \\
\hline & $\mathrm{FE}$ & $\begin{array}{c}0.68 \pm \\
0.28\end{array}$ & 0.69 & $\begin{array}{c}0.63 \pm \\
0.42\end{array}$ & 0.55 \\
\hline \multirow{3}{*}{ M6 } & Serum & $\begin{array}{c}5.70 \pm \\
2.19\end{array}$ & 4.91 & $\begin{array}{c}4.99 \pm \\
1.34\end{array}$ & 5.14 \\
\hline & Urinary & $\begin{array}{c}3.77 \pm \\
1.62\end{array}$ & 3.39 & $\begin{array}{c}4.03 \pm \\
4.24\end{array}$ & 2.86 \\
\hline & $\mathrm{FE}$ & $\begin{array}{c}1.41 \pm \\
1.13\end{array}$ & 1.18 & $\begin{array}{c}1.95 \pm \\
1.39\end{array}$ & 1.47 \\
\hline
\end{tabular}

Mean $(\bar{X})$, standard desviation (s) e median (md).

$\mathrm{A}, \mathrm{B}$ Medians followed by different capital letters on the line differ statistically between groups within the time point by the Wilcoxon Test $(p<0.05)$.

Serum Ca: $11.5-12.8 \mathrm{mg} / \mathrm{dL}$ (KANEKO et al., 2008).
As there are wide variations of minerals and electrolytes in the urine, oscillating according to the absorption and excretion of water (LEFEBVRE et al., 2008), the fractional excretion of the analyzed minerals was calculated.

The FE values of $\mathrm{Ca}$ (Table 6) varied during the experiment from $0.13 \%$ to $1.47 \%$ of the median, being lower than the medians reported by Ferreira et al. (2020) for confined lambs $(1.74 \%$ to $23.03 \%)$. The results of FE Ca in animals in $\mathrm{G} 1$ remained stable from $\mathrm{M} 0$ to $\mathrm{M} 3$, whereas there was an increase in M4 to M5, but they were similar to each other, and in M6, G1 showed higher Ca levels. In G2, M1, M2, M3, and M5 showed mean FE of Ca between $0.231 \%$ and $0.644 \%$, however M0, M4, and M6 returned an increase of $1.097 \%$ to $1.95 \%$. G2 had higher medians than G1 in M0, M1, M3, M4, and M6. During the study, FE revealed an increase when comparing the initial sampling times with the end of the experimental period (M6), due to the greater excretion of $\mathrm{Ca}$, likely related to the longer period of intake of the diet with $0.8 \%$ (G1) and $0.97 \%$ (G2) of Ca.

Serum P measurements (Table 7) ranged from 7.83 to 12.29 $\mathrm{mg} / \mathrm{dL}$, and showed no statistical difference between the groups studied, with hyperphosphatemia in both groups throughout the experiment, due to the high concentrations of $\mathrm{P}$ in the diet. Crookshank et al. (1967) and Hoar et al. (1970) confirmed the importance of phosphorus concentration in the feeding of small ruminants and proved that hyperphosphatemia contributes to the formation of stones (EMERICK; EMBRY, 1963).

The urinary P measurements (Table 7) presented levels between $17.85 \mathrm{mg} / \mathrm{dL}$ and $85.25 \mathrm{mg} / \mathrm{dL}$ with a difference only in $\mathrm{M} 1$, revealing higher medians in G2 compared to G1. The measurements of $\mathrm{FE}$ of $\mathrm{P}$ varied during the experiment from $2.73 \%$ to $22.10 \%$. FE P values in G1 animals at M0, M1, M2, and M3 showed medians between 3.18\% and 5.68\%, while at M4 and M6 the medians were similar to each other, and in M5, G1 higher levels were observed. In the G2, at M0, $\mathrm{M} 2$ and M3, the medians of FE were between $3.77 \%$ and $8.64 \%$, while at M1, M5, and M6 the medians were from $16.16 \%$ to $19.85 \%$. In M4, G2 showed a higher level, reaching $31.81 \%$. G2 returned higher medians than G1 at four times, M0, M1, M3 and M4, suggesting increased urinary $\mathrm{P}$ excretion, which was more evident in the G2 group fed with a higher concentration of $\mathrm{P}(0.65 \%)$ in the diet. This result corroborated that of Hoar et al. (1970), who described those diets rich in $P$ increased serum phosphate, and consequently increased urinary phosphorus excretion, favoring calculogenesis. In contrast, other authors reported hypophosphatemia $(4.0 \pm 3.0 \mathrm{mg} / \mathrm{dL})$ in 107 goats with obstructive urolithiasis (GEORGE; HIRD; GEORGE, 2007), which was not observed in the present study, even in animals that did not present calculus, but were subjected to diets rich in $\mathrm{P}$.

The serum dosages of $\mathrm{Mg}$ (Table 8) ranged from 2.50 $\mathrm{mg} / \mathrm{dL}$ to $4.98 \mathrm{mg} / \mathrm{dL}$. A statistical difference was observed only in M4, when G2 returned a higher median than G1. 
Table 7. Serum (mg/dL), urinary (mg/dL), and FE (\%) of P of feedlot lambs subjected to diets with different levels of phosphorus, $0,43 \%(G 1)$ and $0,65 \%(G 2)$, at different sampling times (M).

\begin{tabular}{|c|c|c|c|c|c|}
\hline \multirow{2}{*}{ Times } & \multirow{2}{*}{ Variables } & \multicolumn{2}{|c|}{ G $1(n=15)$} & \multicolumn{2}{|c|}{ G2 (n= 15) } \\
\hline & & $\bar{X} \pm s$ & md & $\bar{X} \pm s$ & md \\
\hline \multirow{3}{*}{ MO } & Serum & $\begin{array}{c}9.06 \pm \\
2.85\end{array}$ & 7.62 & $\begin{array}{c}9.37 \pm \\
3.87\end{array}$ & 7.83 \\
\hline & Urinary & $\begin{array}{c}45.63 \pm \\
56.91\end{array}$ & 35.05 & $\begin{array}{c}34.28 \pm \\
38.02\end{array}$ & 17.85 \\
\hline & FE & $\begin{array}{c}5.62 \pm \\
4.73\end{array}$ & 4.23 & $\begin{array}{c}3.77 \pm \\
3.83\end{array}$ & 19.91 \\
\hline \multirow{3}{*}{$\mathrm{Ml}$} & Serum & $\begin{array}{c}15.30 \pm \\
10.31\end{array}$ & 11.65 & $\begin{array}{c}9.43 \pm \\
4.01\end{array}$ & 8.62 \\
\hline & Urinary & $\begin{array}{c}47.67 \pm \\
53.45\end{array}$ & $28.60^{B}$ & $\begin{array}{c}104.05 \pm \\
83.57\end{array}$ & $75.00^{A}$ \\
\hline & FE & $\begin{array}{c}3.18 \pm \\
2.70\end{array}$ & $2.73^{B}$ & $\begin{array}{c}16.16 \pm \\
12.81\end{array}$ & $15.38^{A}$ \\
\hline \multirow{3}{*}{$M 2$} & Serum & $\begin{array}{c}10.97 \pm \\
2.71\end{array}$ & 11.14 & $\begin{array}{c}11.25 \pm \\
2.24\end{array}$ & 10.90 \\
\hline & Urinary & $\begin{array}{c}61.50 \pm \\
38.34\end{array}$ & 50.20 & $\begin{array}{c}82.97 \pm \\
86.82\end{array}$ & 62.00 \\
\hline & FE & $\begin{array}{c}5.68 \pm \\
3.40\end{array}$ & 5.23 & $\begin{array}{c}8.64 \pm \\
9.49\end{array}$ & 4.10 \\
\hline \multirow{3}{*}{ M3 } & Serum & $\begin{array}{c}9.63 \pm \\
2.76\end{array}$ & 9.54 & $\begin{array}{c}10.50 \pm \\
2.2\end{array}$ & 10.09 \\
\hline & Urinary & $\begin{array}{l}77.96 \pm \\
72.65\end{array}$ & 67.00 & $\begin{array}{c}119.40 \pm \\
129.88\end{array}$ & 85.25 \\
\hline & FE & $\begin{array}{c}5.59 \pm \\
5.13\end{array}$ & 4.10 & $\begin{array}{c}8.28 \pm \\
6.87\end{array}$ & 5.90 \\
\hline \multirow{3}{*}{ M4 } & Serum & $\begin{array}{c}10.50 \pm \\
4.67\end{array}$ & 9.22 & $\begin{array}{c}11.10 \pm \\
4.39\end{array}$ & 10.43 \\
\hline & Urinary & $\begin{array}{c}59.28 \pm \\
71.76\end{array}$ & 23.80 & $\begin{array}{c}100.81 \pm \\
121.26\end{array}$ & 50.05 \\
\hline & FE & $\begin{array}{c}11.51 \pm \\
10.45\end{array}$ & $10.11^{B}$ & $\begin{array}{c}31.81 \pm \\
33.27\end{array}$ & $22.10^{A}$ \\
\hline \multirow{3}{*}{ M5 } & Serum & $\begin{array}{c}12.08 \pm \\
4.92\end{array}$ & 11.12 & $\begin{array}{c}11.21 \pm \\
4.01\end{array}$ & 10.49 \\
\hline & Urinary & $\begin{array}{c}125.33 \pm \\
110.46\end{array}$ & 82.90 & $\begin{array}{c}100.04 \pm \\
117.70\end{array}$ & 64.85 \\
\hline & FE & $\begin{array}{c}22.67 \pm \\
20.53\end{array}$ & 20.51 & $\begin{array}{c}19.85 \pm \\
16.52\end{array}$ & 18.94 \\
\hline \multirow{3}{*}{ M6 } & Serum & $\begin{array}{c}12.05 \pm \\
3.55\end{array}$ & 12.29 & $\begin{array}{c}11.36 \pm \\
2.79\end{array}$ & 11.54 \\
\hline & Urinary & $\begin{array}{c}63.02 \pm \\
67.42\end{array}$ & 40.20 & $\begin{array}{l}70.91 \pm \\
108.72\end{array}$ & 18.52 \\
\hline & FE & $\begin{array}{c}12.48 \pm \\
12.51\end{array}$ & 10.93 & $\begin{array}{c}16.70 \pm \\
21.89\end{array}$ & 4.78 \\
\hline
\end{tabular}

Mean $(\bar{X}$ ), standard desviation (s) e median (md).

$\mathrm{A}, \mathrm{B}$ Medians followed by different capital letters on the line differ statistically between groups within the time point by the Wilcoxon Test $(p<0.05)$.

Serum P: 5-7.3mg/dL (KANEKO et al., 2008).
Table 8. Serum (mg/dL), urinary ( $\mathrm{mg} / \mathrm{dL})$, and FE (\%) of $\mathrm{Mg}$ of feedlot lambs subjected to diets with different levels of phosphorus, 0,43\% (Gl) and 0,65\%(G2), at different sampling times (M).

\begin{tabular}{|c|c|c|c|c|c|}
\hline \multirow{2}{*}{ Times } & \multirow{2}{*}{ Variables } & \multicolumn{2}{|c|}{ G $1(n=15)$} & \multicolumn{2}{|c|}{ G2 ( $n=15)$} \\
\hline & & $\bar{X} \pm s$ & md & $\bar{X} \pm s$ & md \\
\hline \multirow{3}{*}{ MO } & Serum & $\begin{array}{c}3.75 \pm \\
1.10\end{array}$ & 3.52 & $\begin{array}{c}3.66 \pm \\
0.85\end{array}$ & 3.94 \\
\hline & Urinary & $\begin{array}{c}46.14 \pm \\
19.51\end{array}$ & 39.05 & $\begin{array}{c}38.11 \pm \\
14.41\end{array}$ & 36.35 \\
\hline & $\mathrm{FE}$ & $\begin{array}{c}12.18 \pm \\
7.44\end{array}$ & 10.87 & $\begin{array}{c}10.32 \pm \\
5.10\end{array}$ & 11.25 \\
\hline \multirow{3}{*}{$\mathrm{Ml}$} & Serum & $\begin{array}{c}2.66 \pm \\
0.90\end{array}$ & 2.50 & $\begin{array}{c}2.98 \pm \\
0.81\end{array}$ & 2.96 \\
\hline & Urinary & $\begin{array}{c}32.15 \pm \\
21.80\end{array}$ & $20.70^{\mathrm{B}}$ & $\begin{array}{c}48.43 \pm \\
19.86\end{array}$ & $54.80^{A}$ \\
\hline & $\mathrm{FE}$ & $\begin{array}{c}12.26 \pm \\
8.51\end{array}$ & 9.32 & $\begin{array}{c}21.13 \pm \\
10.58\end{array}$ & 18.48 \\
\hline \multirow{3}{*}{$M 2$} & Serum & $\begin{array}{c}4.33 \pm \\
1.17\end{array}$ & 4.42 & $\begin{array}{c}4.80 \pm \\
0.95\end{array}$ & 4.79 \\
\hline & Urinary & $\begin{array}{c}41.76 \pm \\
14.24\end{array}$ & 43.10 & $\begin{array}{c}38.66 \pm \\
15.28\end{array}$ & 38.55 \\
\hline & FE & $\begin{array}{c}8.95 \pm \\
4.10\end{array}$ & 7.55 & $\begin{array}{c}9.03 \pm \\
3.88\end{array}$ & 9.20 \\
\hline \multirow{3}{*}{ M3 } & Serum & $\begin{array}{c}4.73 \pm \\
0.90\end{array}$ & 4.98 & $\begin{array}{c}4.91 \pm \\
1.01\end{array}$ & 4.80 \\
\hline & Urinary & $\begin{array}{c}33.18 \pm \\
13.31\end{array}$ & $31.15^{\mathrm{B}}$ & $\begin{array}{c}47.01 \pm \\
16.04\end{array}$ & $49.85^{A}$ \\
\hline & $\mathrm{FE}$ & $\begin{array}{c}4.45 \pm \\
2.39\end{array}$ & 4.15 & $\begin{array}{l}6.12 \pm \\
2.246\end{array}$ & 6.03 \\
\hline \multirow{3}{*}{ M4 } & Serum & $\begin{array}{c}2.84 \pm \\
0.93^{\mathrm{B}}\end{array}$ & $2.69^{B}$ & $\begin{array}{c}3.97 \pm \\
2.33\end{array}$ & $3.57^{A}$ \\
\hline & Urinary & $\begin{array}{c}57.30 \pm \\
21.35\end{array}$ & 62.50 & $\begin{array}{c}50.26 \pm \\
18.04\end{array}$ & 48.00 \\
\hline & FE & $\begin{array}{c}43.45 \pm \\
31.89\end{array}$ & 33.20 & $\begin{array}{c}62.26 \pm \\
43.38\end{array}$ & 58.44 \\
\hline \multirow{3}{*}{ M5 } & Serum & $\begin{array}{c}3.99 \pm \\
1.09\end{array}$ & 3.67 & $\begin{array}{c}3.78 \pm \\
1.10\end{array}$ & 3.94 \\
\hline & Urinary & $\begin{array}{c}57.52 \pm \\
20.19\end{array}$ & $65.20^{A}$ & $\begin{array}{c}41.71 \pm \\
17.23\end{array}$ & $40.05^{B}$ \\
\hline & $\mathrm{FE}$ & $\begin{array}{c}26.24 \pm \\
7.68\end{array}$ & $23.57^{A}$ & $\begin{array}{c}25.15 \pm \\
13.85\end{array}$ & $21.37^{B}$ \\
\hline \multirow{3}{*}{ M6 } & Serum & $\begin{array}{c}3.44 \pm \\
1.24\end{array}$ & 3.03 & $\begin{array}{c}3.63 \pm \\
0.90\end{array}$ & 3.73 \\
\hline & Urinary & $\begin{array}{c}52.37 \pm \\
28.15\end{array}$ & 62.70 & $\begin{array}{c}49.49 \pm \\
23.14\end{array}$ & 53.25 \\
\hline & $\mathrm{FE}$ & $\begin{array}{c}27.36 \pm \\
16.60\end{array}$ & 29.12 & $\begin{array}{c}32.30 \pm \\
17.19\end{array}$ & 30.39 \\
\hline
\end{tabular}

Mean $(\bar{X}$ ), standard desviation (s) e median (md).

$A, B$ Medians followed by different capital letters on the line differ statistically between groups within the time point by the Wilcoxon Test $(p<0.05)$.

Serum Mg: 2.2-2.8mg/dL (KANEKO et al., 2008). 
The urinary $\mathrm{Mg}$ dosage had levels between $20.70 \mathrm{mg} / \mathrm{dL}$ and $65.20 \mathrm{mg} / \mathrm{dL}$, with statistical differences between the groups in M1, M3, and M5. At M1 and M3, G2 showed higher medians compared to G1. The FE of $\mathrm{Mg}$ varied during the experiment from $4.15 \%$ to $58.44 \%$. The FE values of $\mathrm{Mg}$ showed different medians in $\mathrm{G} 1$ at $\mathrm{M} 0, \mathrm{M} 1, \mathrm{M} 2$, and $\mathrm{M} 3$, with variation between $4.15 \%$ and $10.32 \%$, whereas in M5 and M6 there were medians of $23.57 \%$ and $29.12 \%$, respectively. M4, however, revealed the highest median FE (33.20\%). In G2, M0, M1, $\mathrm{M} 2$, and M3 presented medians between $6.03 \%$ and $18.48 \%$. M5 and M6 obtained similar medians, $21.37 \%$ and $30.39 \%$, respectively. M4 returned the highest median (58.44\%) of all sample points. G2 showed higher medians than G1 in M0, M1, M2, M3, M4, and M6. Throughout the experimental period, the FE of Mg increased significantly from M3 to M4, remaining high until the end, possibly related to the chronic ingestion of the concentrate-rich diet.

Changes in $\mathrm{Mg}$ metabolism are determining factors in the development of urolithiasis, although abnormal $\mathrm{P}$ metabolism is also a requirement (KUNKEL et al., 1953). In a study by Haag and Palmer (1928), it was noticed that when rats were supplemented with diets containing a high concentration of $\mathrm{Mg}$ and $\mathrm{P}$, there was a greater occurrence of phosphate calculations. In the present study, similar to the findings with $\mathrm{FE}$ of $\mathrm{P}, \mathrm{Mg}$ showed a higher urinary concentration at the end of the experiment, which showed a synergism between these elements.

\section{CONCLUSIONS}

Under the conditions of this experiment, following the recommendations of $\mathrm{Ca}$ and $\mathrm{P}$ proportionality (1:1 to $2: 1)$ in the literature, it was concluded that both diets promoted calculogenesis in lambs. In addition, the concentration of these elements should be considered in the nutritional planning of diets, as the levels of minerals are often higher than expected. From the results obtained, it is not possible to suggest precise levels for the elaboration of a diet; however, caution is necessary regarding the concentrations of these minerals. The relevance of conducting chemical-bromatological analysis of food is emphasized, and in a complementary way, laboratory tests for the diagnosis of urolithiasis.

\section{ACKNOWLEDGMENTS}

The authors would like to thank FMVZ/UNESP, Campus Botucatu, SP, Brazil for the physical structure and equipment used to carry out the experiment and FAPESP (Sáo Paulo State Research Support Foundation) for Regular Research Assistance granted [Process number 2012/22620-8].

\section{REFERENCES}

ANTONELLI, A. C. et al. Efeito de diferentes fontes energéticas na predisposição para urolitíase em cabritos. Ciência Animal Brasileira, v. 13, n. 4, p. 487-93, 2012.

ARAÚJO, P.B. et al. Urinálise como instrumento auxiliar no diagnóstico de enfermidades em pequenos ruminantes. Medicina Veterinária, v. 3, п. 2, p. 30-38, 2009.

BRANCHINI, N. S. Estudo da influência alimentar na etiologia da urolitíase em cordeiros. Dissertação (Mestrado) - Faculdade de Medicina Veterinária e Zootecnia, Universidade Estadual Paulista, Botucatu, 2014.

CIRNE, L. G. A. et al. Desempenho de cordeiros em confinamento alimentados com dieta exclusiva de concentrado com diferentes porcentagens de proteína. Arquivo Brasileiro de Medicina Veterinária e Zootecnia, v. 65, n. 1, p. 262-266, 2013.

CROOKSHANK, H. R.; ROBBINS, J. D.; KUNKEL, H. O. Relationship of dietary mineral intake to serum mineral level and the incidence of urinary calculi in lambs. Journal of Animal Science, v. 26, n. 5, p. 1179-1185, 1967.

EMERICK, R. J.; EMBRY, L. B. Calcium and phosphorus levels related to the development of phosphate urinary calculi in sheep. Journal of Animal Science, v. 22, n. 2, p. 510-513, 1963.

FERREIRA, D. O. L. et al. Baixo desempenho da vitamina C comparado ao cloreto de amônio como acidificante urinário em cordeiros confinados. Ciência animal brasileira, v. 2l, 2020.
FERREIRA, D. O. L. et al. Efeito da suplementação de cloreto de amônio sobre o equilíbrio ácido-básico e o pH urinário de ovinos confinados. Pesquisa Veterinária Brasileira, v. 34, n. 8, p. 797$804,2014$.

FERREIRA, D. O. L. et al. Excreção fracionada urinária de sódio, potássio e cloreto em cordeiros suplementados com cloreto de amônio para prevenção de urolitíase. Pesquisa Veterinária Brasileira. v. 38, n. 5, p. 870-874, 2018.

FERREIRA, D. O. L. et al. Urolitíase obstrutiva em ovinos. Veterinária e Zootecnia, v. 22, п. 2, p. 183-197, 2015.

FLEMING, S. A. et al. Renal "clearance" and fractional excretion of electrolytes over four 6-hour periods in cattle. American Journal of Veterinary Research, v. 52, p. 5-8, 1991.

FREEMAN, S. R. et al. Influence of calcium ( 0.6 or $1.2 \%$ ) and phosphorus ( 0.3 or $0.6 \%$ ) content and ratio on the formation of urolithogenic compounds in the urine of Boer-cross goats fed high-concentrate diets. Small Ruminant Research, v. 93, п. 2-3, p. 94-102, 2010.

GARCIA-NAVARRO, C. E. K. Manual de Urinálise Veterinária. 1. ed. São Paulo: Livraria Varela, 2005.

GEORGE, J. W.; HIRD, D. W.; GEORGE, L. W. Serum biochemical abnormalities in goats with uroliths: 107 cases (1992-2003). Journal of American Veterinary Medicine Association, v. 230, ก. 1, 2007. 
GERASEEV, L. C. et al. Composição Corporal e Exigências Nutricionais em Cálcio e Fósforo para Ganho e Mantença de Cordeiros Santa Inês dos $15 \mathrm{~kg}$ aos $25 \mathrm{~kg}$ de Peso Vivo. Revista Brasileira de Zootecnia, v. 29, п. 1, p. 261-268, 2000.

GUIMARÃES, J. A. et al. Estudo retrospectivo de 66 casos de urolitíase obstrutiva em ovinos. Pesquisa Veterinária Brasileira, v. 32, п. 9, p. 824-830, 2012.

HAAG J. R.; PALMER L. S. The effect of variations in the proportions of calcium, magnesium and phosphorus container in the diet. Journal of Biological Chemistry, v.76, p.367-389, 1928.

HOAR, D. W.; EMERICK, R. J.; EMBRYL. B. Potassium, phosphorus and calcium interrelationship in influencing feedlot performance and phosphoric urolithiasis in lambs. Journal of Animal Science, v.30, n. 4, p. 597-600, 1970.

JONES, M. L. et al. Mineral Composition of Uroliths Obtained from Sheep and Goats with Obstructive Urolithiasis. Journal of Veterinary Internal Medicine, v. 31, p. 1202-1208, 2017.

KANEKO, J. J.; HARVEY, J. W.; BRUSS, M. L. Clinical biochemistry of domestic animals. 6.ed. San Diego: Academic, 2008.

KING, C. Practical use of urinary fractionated excretion. Journal of Equine Veterinary Science, v. 14, p. 464-468, 1994.

KIRSZTAJN, G. M. Avaliação do ritmo de filtração glomerular. Jornal Brasileiro de Patologia e Medicina Laboratorial, v. 43, p. 257-264, 2007.

KOZLOSKI, G. V. et al. Uso da creatinina como indicador da excreção urinária em ovinos. Ciência Rural, v. 35, p. 98-102, 2005.

KUNKEL, H. O.; BURNS, K. H.; CAMP, B. J. A study of sheep fed high levels of potassium bicarbonate with particular reference to induced hypomagnesemia. Journal ofAnimalScience, v. 12, n. 3, p.451-458,1953.

LEFEBVRE, H. P. et al. Fractional excretion tests: a critical review of methods and applications in domestic animals. Veterinary Clinical Pathology, v. 37, n. 1, p. 4-20, 2008.

LOUVANDINI, H.; VITTI, D. M. S. S. Perda endógena de fósforo em ovinos com diferentes níveis do elemento na dieta. Pesquisa Agropecuária Brasileira, v. 29, p. 145-149, 1994.
MACIEL, T. A. et al. Avaliação dos perfis minerais séricos, urinários e sedimentares de ovinos recebendo dieta calculogênica. Arquivo Brasileiro de Medicina Veterinária e Zootecnia, v. 68, n. 4, p. 967-976, 2016.

MACIEL, T. A. et al. Clinical and Biochemical Profile of Obstructive Urolithiasis in Sheep. Acta Scientiae Veterinariae, v. 45, 2017.

NATIONALRESEARCH COUNCIL(NRC). Nutrient Requirements of Small Ruminants: sheep, goats, cervids and New World camelids. Washington: Natl Acad. Press, 2007.

PIRES, C. C. et al. Cria e terminação de cordeiros confinados. Ciência Rural, v. 30, n. 5, p. 875-880, 2000.

RENNÓ, L. N. et al. Concentração plasmática de ureia e excreções de ureia e creatinina em novilhos. Revista Brasileira de Zootecnia, v. 29, п. 24, p. 1234-1243, 2000.

RIET-CÔRREA, F.; SIMÕES, S. V. D.; VASCONCELOS, J. S. Urolitíase em caprinos e ovinos. Pesquisa Veterinária Brasileira, v. 28, p. 319-322, 2008.

SACCO, S. R.; LOPES, R. S. Urolitíase: estudo comparativo em bovinos Guzerá oriundos de propriedades com e sem o problema. Pesquisa Veterinária Brasileira, v. 31, n. 3 p. 206-212, 2011.

SUN, W. D. et al. The chemical composition and ultrastructure of uroliths in Boer goats. The Veterinary Journal, v. 186, n.l, p. 70-75, 2010.

TIRUNEH, R. Ruminant urolithiasis in Ethiopia: alterations of mineral concentrations in bovine urine and sheep sera according to the geographic origin or the diet regimen. Revue de Médecine Vétérinaire, v.157. n.5, p.26l-264, 2006.

VAN SOEST, P. J.; WINE, R. H. The determination of lignin and cellulose in acid-detergent fibre with permanganate. Journal of the Association of Official Analytical Chemists, v. 51, p. 780785, 1968.

VINODHKUMAR O.R. et al. Clinical, mineral and haemato-biochemical studies of urolithiasis in wearner lambs. African Journal of Agricultural Research, v. 5, n. 15, p.2045-2050, 2010. 